\title{
Clinical biomarkers and molecular basis for optimized treatment of diabetic retinopathy: current status and future prospects
}

This article was published in the following Dove Press journal:

Eye and Brain

19 February 2016

Number of times this article has been viewed

\author{
Rohit Saxena' \\ Digvijay Singh ${ }^{2}$ \\ Ravi Saklani ${ }^{3}$ \\ Suresh Kumar Gupta ${ }^{3}$ \\ 'Dr Rajendra Prasad Centre for \\ Ophthalmic Sciences, All India \\ Institute of Medical Sciences, New \\ Delhi, ${ }^{2}$ Division of Ophthalmology, \\ Medanta-The Medicity, Gurgaon, \\ ${ }^{3}$ Ocular Pharmacology Laboratory, \\ Delhi Institute of Pharmaceutical \\ Sciences and Research, New Delhi, \\ India
}

\begin{abstract}
Diabetic retinopathy is a highly specific microvascular complication of diabetes and a leading cause of blindness worldwide. It is triggered by hyperglycemia which causes increased oxidative stress leading to an adaptive inflammatory assault to the neuroretinal tissue and microvasculature. Prolonged hyperglycemia causes increased polyol pathway flux, increased formation of advanced glycation end-products, abnormal activation of signaling cascades such as activation of protein kinase $\mathrm{C}$ ( $\mathrm{PKC}$ ) pathway, increased hexosamine pathway flux, and peripheral nerve damage. All these changes lead to increased oxidative stress and inflammatory assault to the retina resulting in structural and functional changes. In addition, neuroretinal alterations affect diabetes progression. The most effective way to manage diabetic retinopathy is by primary prevention such as hyperglycemia control. While the current mainstay for the management of severe and proliferative diabetic retinopathy is laser photocoagulation, its role is diminishing with the development of newer drugs including corticosteroids, antioxidants, and antiangiogenic and anti-VEGF agents which work as an adjunct to laser therapy or independently. The current pharmacotherapy of diabetic retinopathy is incomplete as a sole treatment option in view of limited efficacy and short-term effect. There is a definite clinical need to develop new pharmacological therapies for diabetic retinopathy, particularly ones which would be effective through the oral route and help recover lost vision. The increasing understanding of the mechanisms of diabetic retinopathy and its biomarkers is likely to help generate better and more effective medications.
\end{abstract}

Keywords: mechanism, pharmacotherapy microvascular changes, neurodegeneration, laser, progression

\section{Introduction}

Diabetic retinopathy (DR) is a highly specific neuroretinal and microvascular complication of diabetes caused by various abnormal metabolic pathways triggered by uncontrolled hyperglycemia. Initially, the disease is asymptomatic, but prolonged poor control of diabetes leads to permanent pathological changes in the retina resulting in blurred vision, floaters, distortion, and complete loss of vision. ${ }^{1-6}$ These pathological changes include microaneurysms, hemorrhages and exudates (nonproliferative DR [NPDR]), formation of new abnormal blood vessels or retinal neovascularization (proliferative DR [PDR]), and diabetic macular edema (DME).

DR is emerging as one of the leading causes of blindness in both developing and developed countries. It is estimated that nearly 400 million people are affected with diabetes worldwide and the number is likely to reach close to 600 million by $2035 .^{7,8}$ Over 90 million people are estimated to be suffering from DR, of which 17 million have PDR, 21 million have DME, and 28 million have severe vision-threatening DR. ${ }^{9,10}$ 
A thorough and enhanced understanding of the various pathways and clinical biomarkers involved in the pathogenesis of DR is a prerequisite to developing therapeutic strategies. At the molecular level, the etiology of DR is highly complex, with numerous interlinked mechanisms causing adaptive, functional, and structural changes in both the microvasculature and neuroglia. These in turn lead to cellular damage in the retina which is often permanent. However, despite extensive research, the understanding of these pathways remains limited and the initiator of the DR cascade is unclear. ${ }^{3,5,9}$

It is currently understood that prolonged hyperglycemia causes increased polyol pathway flux, ${ }^{11,12}$ increased advanced glycation end-product (AGE) formation, ${ }^{13,14}$ abnormal activation of signaling cascades such as activation of protein kinase C (PKC) pathway, ${ }^{15-17}$ increased hexosamine pathway flux,,$^{10,18-22}$ and peripheral nerve damage. ${ }^{23}$ All these changes lead to increased oxidative stress ${ }^{19,24-27}$ and inflammatory assault $t^{28-31}$ to the retina resulting in adaptive structural and functional changes. ${ }^{9,32,33}$

Progression of DR is characterized by loss of pericytes, basement membrane thickening, formation of microaneurysms, neovascularization, and blood-retinal barrier breakdown. ${ }^{9}$ The disease progresses through increased vascular permeability and retinal ischemia resulting in retinal neovascularization and retinal thickening. ${ }^{34}$

Conventionally, the clinical classification, etiology, and management strategy of DR were solely based on microvascular changes in the retina. The role of neuroretinal alterations in the etiology of DR were not recognized until the 1960s, when Wolter ${ }^{35}$ and Bloodworth ${ }^{36}$ documented the pathological degeneration of neurons in the retina of diabetic patients. Although the exact relation between neuroretinal changes and DR is still unclear, research over the past decade has enhanced our understanding about various neuroretinal pathways and clinical biomarkers involved in the pathogenesis of DR. The role of neuroretinal alterations and neuroretinal inflammation in the formation and progression of DR is apparent, and therapies targeting the prevention of neuroretinal damage from diabetes are also underway in different stages of clinical and preclinical trials. ${ }^{37,38}$

\section{Biomarkers and mechanisms for microvascular dysfunction Glycemic level}

Evidence of hyperglycemia and its duration as a major risk factor in the progression of DR is plentiful. ${ }^{10,39} \mathrm{In}$ diabetes, due to prolonged exposure to high blood glucose concentration, endothelial cells lining the microvasculature experience oxidative stress and cause increased adhesive interactions between circulating inflammatory cells and additionally activate them. This leads to increased synthesis of inflammatory mediators by blood and endothelial cells promoted by cytokines. ${ }^{26}$

\section{Lipid level}

Dyslipidemia is found to increase the risk of DR, especially DME..$^{40-42}$ The exact role of an increased lipid level in the progression of DR remains unclear, but it is hypothesized that high lipid levels cause endothelial dysfunction due to a decreased bioavailability of nitric oxide and peroxidation of lipid by increased oxidative stress associated with hyperglycemia which is responsible for retinal exudate formation in DR. ${ }^{40}$

\section{Aldose reductase (polyol pathway)}

In a hyperglycemic state, excess intracellular glucose enters the polyol pathway and is reduced by aldose reductase to sorbitol accompanied by expenditure of NADPH and reduction of glutathione level. Increased sorbitol levels cause osmotic stress, and reduced levels of NADPH and glutathione cause impairment of antioxidant defense mechanisms resulting in oxidative damage to retina and capillary cells. Increased expression of aldose reductase has been implicated in the pathogenesis of DR and inhibition of the same may control progression of DR. ${ }^{11,12,43}$

\section{TGF- $\beta$ I and plasminogen activation inhibitor-I (hexosamine pathway)}

In a hyperglycemic condition, excess glucose is diverted from glycolysis to the hexosamine pathway, which produces substrates such as proteoglycan and $O$-linked glycoproteins. These substances are responsible for many manifestations of DR. Substrates produced in this pathway cause intracellular glycation of transcription factor SP1 at serine and threonine location in the transcribed protein, which is consequently responsible for increased expression of TGF- $\beta 1$ and PAI- 1 . TGF- $\beta 1$ is involved in the production of extracellular matrix protein and PAI-1 inhibits the fibrinolysis. Overexpression of these two biomarkers together causes retinal vein occlusion. ${ }^{44}$

\section{Vascular endothelial growth factor (angiogenic biomarkers)}

Vascular endothelial growth factor (VEGF) is an important endothelial cell-specific angiogenic and permeability-inducing inflammatory agent. It is an important biomarker and plays a causative role in the development of DR. If the level of 
VEGF is maintained, then the progression of DR is controlled substantially. ${ }^{41}$

\section{PKC- $\beta$}

PKC- $\beta$ is an important biomarker in DR and mediates a variety of undesirable functional and structural changes in vascular tissues. In diabetes, prolonged hyperglycemia results in increased diacylglycerol level, which triggers the activation of PKC- $\beta$. The PKC- $\beta$ level is raised in the retina of patients with DR. Activation of PKC- $\beta$ causes phosphorylation of many important intracellular proteins leading to initiation of a cascade of reactions resulting in activation or inhibition of many enzymes responsible for abnormal changes in blood flow, loss of capillary pericytes, and increased endothelial permeability. It also causes retinal leakage, ischemia, and neovascularization in conjunction with angiogenic growth factors, all of which lead to progression of DR. ${ }^{16,45}$

\section{Tumor necrosis factor alpha (inflammatory biomarker)}

Tumor necrosis factor (TNF)- $\alpha$ is a proinflammatory cytokine responsible for inflammation and apoptotic cell death of retinal endothelial cells. The introduction of TNF- $\alpha$ antagonists for the management of DR in an early stage can reduce the diabetes-induced retinal cell death and progression of DR. ${ }^{28,46,47}$

\section{IL-I $\beta$ (inflammatory biomarker)}

$\mathrm{IL}-1 \beta$ is a proinflammatory cytokine, levels of which are reported to be upregulated in the vitreous humor of patients suffering from PDR. ${ }^{9,10}$ Elevated vitreous levels of IL-1 $\beta$ are implicated in modulating the inflammatory process by stimulating various cells to release inflammatory signals which cause disruption of the blood-retinal barrier and retinal capillary cell apoptosis. ${ }^{46-48}$ Another inflammatory biomarker is IL-6, which is associated with increased apoptosis and cell death.

\section{Basement membrane thickening}

Thickening of the capillary basement membrane is the hallmark of DR. Prolonged hyperglycemia stimulates the messenger RNA expression of extracellular matrix proteins in retinal endothelial cells, which leads to increased generation and decreased degradation of the extracellular matrix proteins and thickened capillary basement membrane. ${ }^{49,50}$

\section{Growth hormone}

The role of growth hormone in the progression of diabetes is not clear, but its role in the development of DR is confirmed by improvement in retinopathy following hypophysectomy in diabetic patients. ${ }^{51,52}$

\section{AGEs and receptor of AGEs}

Hyperglycemia causes nonenzymatic glycation of proteins, lipids, or nucleic acids producing irreversible cross-linked complex compounds known as AGEs. Important examples of AGEs associated with progression of DR in humans are carboxyethyllysine, carboxymethyllysine, and pentosidine. ${ }^{9}$ Increased levels of AGEs are found accumulated in retinal pericytes of patients suffering from DR. Interaction of AGEs with the receptor of AGEs (RAGEs) form AGE-RAGE complexes which provoke the activation of critical cell signaling pathways, such as p21 ras, mitogen-activated protein kinases (MAPKs), and nuclear factor- $\kappa \mathrm{B}(\mathrm{NF}-\kappa \mathrm{B})$. All this leads to the activation of proinflammatory responses, causing injury to endothelial cells and disruption of the blood-retinal barrier. ${ }^{53,54}$

\section{Oxidative stress}

Prolonged hyperglycemia causes alteration in regular biochemical pathways and reduction in antioxidant enzyme (SOD, CAT, or GSH) and coenzyme (NADH) levels in the retina. Impairment of the body's antioxidant defense mechanism causes oxidation of cellular macromolecules, causing further oxidative damage to the retina..$^{5-57}$

\section{Biomarkers and mechanisms for neurodegeneration}

Neurodegeneration is a very early event in the progression of DR, preceding the clinically apparent signs associated with DR. Changes in physiological structure and function in the neuroretinal compartment of diabetic patients manifest as alterations in normal physiological constriction and dilation of blood vessels (which occur in response to stimuli such as oxygen and flickering light, respectively). ${ }^{58-62}$ Other preclinical pathological changes observed include decreased multifocal electroretinogram potentials, ${ }^{63,64}$ decreased contrast sensitivity, ${ }^{65}$ delayed dark adaptation, ${ }^{66,67}$ abnormalities on frequency doubling perimetry, ${ }^{66,68}$ and reduction in retinal ganglion cell layer thickness on optical coherence tomography (OCT). ${ }^{37,69,70}$

\section{Insulin receptors}

Insulin receptors in the retina are important for anabolic synthesis, survival, growth, and development of neurons. ${ }^{71-73}$ In diabetes, a deficiency of insulin and/or its action is associated with apoptosis of neurons and ganglion cells leading to 
DR. This is shown by the prevention of neurodegeneration and DR in diabetic rats treated with insulin. ${ }^{74,75}$

\section{Molecular pathways}

Activation of a PKC pathway, increased flux by the polyol pathway, formation of AGEs, and increased oxidative stress provoked by a prolonged hyperglycemic condition is also found to damage the neuroretinal compartment along with retinal microvasculature. ${ }^{37,38}$

\section{Neuroinflammation}

In diabetes, the level of inflammatory markers such as TNF- $\alpha$ is raised and plays an important role in the leukostasis and apoptosis of neural cells which are responsible for the progression of DR. ${ }^{37,38}$

\section{Glutamate excitotoxicity}

Glutamate plays an important role in communication between neurons. Prolonged hyperglycemia causes a reduction in the activity of the enzyme glutamine synthetase and oxidation of glutamate, which leads to a glutamate and glutamine disequilibrium in neurons and glial cells. The increased level of glutamate in diabetes is associated with glutamate excitotoxicity which increases calcium influx and initiates proapoptotic signaling cascades. ${ }^{37,38}$ Such events are likely to be involved in the apoptosis of neurons within the retina in diabetes. ${ }^{76-78}$

\section{Deficiency of neuroprotective factors}

The neuronal compartment possesses certain neuroprotective local factors including pigment epithelium-derived factor (PEDF), ${ }^{79-82}$ brain-derived neurotrophic factor (BDNF), ${ }^{83,84}$ and nerve growth factor (NGF). ${ }^{85,86}$ It is postulated that they protect against oxidative stress and glutamate excitotoxicity, thereby having a critical role in the prevention of neuronal damage associated with DR. In diabetes, the level or activity of these factors is reduced and neurodegeneration occurs. ${ }^{37}$

\section{Apoptosis}

In diabetes, the exact mechanism of apoptosis of retinal neurons and vascular cells is not known. It is believed that apoptotic cascades are triggered by the combined action of hyperglycemia, glutamate excitotoxicity, and neurotrophins, ultimately leading to neuronal cell death and DR. ${ }^{75,85,87}$

\section{Interlinked molecular pathways}

DR has a multifactorial etiology with various interconnecting biochemical pathways acting in conjunction and leading to oxidative and inflammatory damage to the retina. ${ }^{88}$ In prolonged hyperglycemia, surplus glucose enters the polyol pathway and is reduced to sorbitol, which gets further converted to fructose. An increased sorbitol level in the retina causes osmotic stress and predisposes the retina to oxidative damage due to expenditure of NADPH and a reduced glutathione level. In addition, the by-products of the polyol pathway, fructose-3-phosphate and 3-deoxyglucosone form irreversible cross-linked complex compounds with proteins, lipids, and nucleic acids (AGEs). AGE interaction with its receptor forms AGE-RAGE complexes which further provoke the critical cell signaling pathways such as the PKC pathway, p21ras, MAPKs, NF- $\mathrm{BB}$, and poly (ADP-ribose) polymerase. This leads to endothelial cell injury and disruption of the blood-retinal barrier. An increased flux through the hexosamine pathway causes increased TGF- $\beta$ expression, PKC activation, and extracellular matrix production, which escalate the blood-retina barrier breakdown. All these pathways also cause activation of a proinflammatory response, oxidative stress, and growth factor imbalances leading to progression of DR. ${ }^{9}$

\section{Clinical biomarkers Microaneurysm turnover}

The rate of formation of new microaneurysms is shown to be linked to increased risk of development of clinically significant macular edema. A higher rate of microaneurysm formation indicates a higher likelihood of disease progression. ${ }^{89,90}$ Microaneurysm turnover is also associated with disease severity as measured by the ETDRS (Early Treatment Diabetic Retinopathy Study) severity level. ${ }^{91}$

\section{OCT changes}

OCT has become a mainstay in the diagnosis and management of DR, particularly macular involvement. Detection of subclinical macular edema has added an enhanced sensitivity to detection of the disease and its progression. . $^{6,70,92-94}$

\section{Visual acuity}

Patients with DR are shown to have lower visual acuity than those without a retinopathy. Visual acuity has shown a negative correlation with disease duration and severity of ocular damage in patients with retinopathy. ${ }^{95}$

\section{Perimetry}

Visual field deterioration does not correlate with a change in retinopathy. ${ }^{66}$ By using perimetry with an analysis tailored for monitoring diabetic subjects, it has been possible to demonstrate progression of retinal dysfunction over time, which may 
represent early signs of retinal neurodegeneration. Special forms of perimetry including frequency doubling perimetry have also been studied as potential biomarkers for DR. ${ }^{66,68,96,97}$

\section{Fluorescein angiography}

Studies have found that a greater macular ischemia grade as noted by the increasing foveal avascular zone is independently predictive for progression, and the progression of diabetic macular ischemia itself is predictive of the loss of visual function. The role of peripheral ischemia as a biomarker for progression is uncertain..$^{98,99}$

\section{Electrophysiology}

In DR, the oscillatory potentials of electrooculography can monitor the progression of disease and indicate neuronal alterations rather than diabetic angiopathy. Multifocal electroretinogram has also been shown to predict onset and development of localized DR. ${ }^{63,64,82,94,100,101}$

\section{Management of DR}

DR is a disorder with a multifactorial etiology and hence its management is also complex. It requires a multidisciplinary approach and needs to be individualized according to severity of the disease and patient response. Table 1 describes the various stages of DR and preferred clinical treatment modality.

\section{Primary/preventive interventions Glycemic control}

Good glycemic control early in the course of the disease is beneficial in reducing the incidence and progression of DR. According to a Diabetes Control and Complications Trial (DCCT) report, the risk of progression of retinopathy in diabetes can be reduced by $25 \%$ in type 1 and $39 \%$ in type 2 diabetes with each $1 \%$ decrease in glycated hemoglobin $\left(\mathrm{HbA}_{1 \mathrm{c}}\right)$ level. ${ }^{104}$ Maintaining a glycemic level below 6.5 $\mathrm{mmol} / \mathrm{L}$ or $117 \mathrm{mg} / \mathrm{dL}$ (fasting plasma glucose) and $\mathrm{HbA}_{1 \mathrm{c}}$ level below 7\% is the target in the ideal management of DR. If these targets are met, then the progression of DR can be stopped or slowed down significantly. ${ }^{102,103}$ Though the risk of early worsening of DR following the initiation of intensive insulin therapy was documented in a DCCT report, it is reversed by 18 months, and, in the long term, intensive glycemic control is beneficial in reducing the incidence and progression of DR. ${ }^{104}$

\section{Blood pressure control}

Evidence that blood pressure is a major risk factor in the progression of DR is not apparent, but it is a modifiable risk factor in the progression of DR. ${ }^{105,106}$ Controlling systolic $(<130 \mathrm{mmHg})$ and diastolic blood pressure is found to be beneficial in reducing loss of vision due to DR. According

Table I International DR disease severity scale and recommended management strategies ${ }^{146,147}$

\begin{tabular}{|c|c|c|}
\hline Disease severity level & Signs & Management options \\
\hline $\begin{array}{l}\text { No apparent } \\
\text { retinopathy }\end{array}$ & No abnormalities. & Optimize medical therapy of glucose, blood pressure, and lipids. \\
\hline Minimal NPDR & Microaneurysms only. & Optimize medical therapy of glucose, blood pressure, and lipids. \\
\hline Mild-to-moderate & More than just microaneurysms but less than severe & Optimize medical therapy of glucose, blood pressure, and lipids \\
\hline NPDR & NPDR. & and ophthalmology referral. \\
\hline Severe NPDR & $\begin{array}{l}\text { Any of the following: more than } 20 \text { intraretinal } \\
\text { hemorrhages in each of four quadrants; definite venous } \\
\text { beading in two or more quadrants; and prominent } \\
\text { intraretinal microvascular abnormalities in one or more } \\
\text { quadrants and no signs of proliferative retinopathy. }\end{array}$ & $\begin{array}{l}\text { Consider scatter (panretinal) laser treatment for patients with } \\
\text { type } 2 \text { diabetes. } \\
\text { Optimize medical therapy of glucose, blood pressure, } \\
\text { and lipids. }\end{array}$ \\
\hline PDR & $\begin{array}{l}\text { One of the following: neovascularization or vitreous/ } \\
\text { preretinal hemorrhage. }\end{array}$ & $\begin{array}{l}\text { Strongly consider scatter (panretinal) laser treatment, without } \\
\text { delay for patients with vitreous hemorrhage or neovascularization } \\
\text { within one disc diameter of the optic nerve head. } \\
\text { Optimize medical therapy of glucose, blood pressure, and lipids. }\end{array}$ \\
\hline \multicolumn{3}{|l|}{ Macular edema } \\
\hline Absent & No retinal thickening or hard exudates in posterior pole. & Laser treatment for PDR and center not involving DME. \\
\hline Present & $\begin{array}{l}\text { Mild - some retinal thickening or hard exudates in } \\
\text { posterior pole but distant from the macula. } \\
\text { Moderate - retinal thickening or hard exudates } \\
\text { approaching the center of the macula but not involving } \\
\text { the center. } \\
\text { Severe - retinal thickening or hard exudates involving } \\
\text { the center of the macula. }\end{array}$ & $\begin{array}{l}\text { Intravitreal drug administration for center involving DME and } \\
\text { eventual additional later laser treatment. } \\
\text { Vitrectomy as a microsurgical approach for traction-induced } \\
\text { DME, later changes in PDR such as vitreous hemorrhage, and } \\
\text { tractional retinal detachment, sometimes in conjunction with } \\
\text { prior intravitreal anti-VEGF treatment. }\end{array}$ \\
\hline
\end{tabular}

Abbreviations: DME, diabetic macular edema; DR, diabetic retinopathy; NPDR, nonproliferative DR; PDR, proliferative DR. 
to the UKPDS, lowering the systolic blood pressure by $10 \mathrm{mmHG}$ decreases the risk of DR progression by $13 \%$ irrespective of blood glucose level. ${ }^{107}$ Certain antihypertensive agents may actually be responsible for the beneficial effect of lowering blood pressure on the progression of diabetes rather than reduced blood pressure itself. This is supported by the benefit documented in using certain agents in normotensive diabetic patients. The angiotensin-converting enzyme (ACE) and renin-angiotensin system ${ }^{108}$ are expressed in retina where these agents are hypothesized to be affecting VEGF expression. Lisinopril, ${ }^{109}$ an ACE inhibitor, is proved to be beneficial in reducing the progression of DR. $\beta$-Blockers are also found to be efficient in reducing the progression of DR. ${ }^{107}$

\section{Lipid control}

Studies suggest fenofibrate and simvastatin play a role in reducing the incidence of DME and need for laser treatment by controlling the macular hard exudate deposition. ${ }^{110,111}$ However, another study found no significant role of lipid level in progression of DR or improvement in vision loss in patients treated with hypolipidemic agents. ${ }^{40}$ Due to the contradictions of previous studies, the roles of lipid control and hypolipidemic agents remain inconclusive in DR, but treatment with hypolipidemic agents in diabetic patients with a high lipid level is considered beneficial and adjunctive to conventional treatment.

\section{Secondary/therapeutic interventions Retinal laser photocoagulation}

Retinal laser photocoagulation refers to the process of firing laser spots at the retina in order to burn a part of the diseased retina. It can either be panretinal photocoagulation (PRP) or focal laser photocoagulation. PRP is the gold-standard technique in the treatment of very severe NPDR, PDR, and DME. ${ }^{112-114}$ In this technique, a laser is used to deliver spots on the retina to burn and destroy ischemic retina which is releasing proinflammatory and proangiogenic compounds that increase the severity of retinopathy. PRP reduces the risk of vision loss by $50 \%$ in PDR. In mild-to-moderate NPDR, however, it is discouraged over primary interventions due to its adverse effects, which include risk of severe vision loss due to traction retinal detachment or accidental laser burn of the fovea, vitreous hemorrhage, field constriction, color blindness, night blindness, glaucoma, and macular edema exacerbation. ${ }^{115}$ Focal laser photocoagulation refers to using a laser beam on a small area of the retina or a localized lesion in order to seal faulty, leaky blood vessels, thereby maintaining the function and thickness of the retina. It aims to alleviate loss of vision to a great extent, particularly in the less severe stages of DR. Adverse effects include accidental central retinal burns causing permanent central vision loss. The role of laser treatment for DR is now dwindling with the advent of newer drugs which help control macular edema and retinal neovascularization effectively. However, due to the unavailability of an effective oral drug and limited period of action of these newer antiangiogenic agents, laser still forms the mainstay of managing severe NPDR, PDR, and DME.

\section{Vitrectomy}

Vitreous surgery is indicated in cases of DR causing vitreous hemorrhage or retinal traction or a retinal detachment. It is also beneficial in case of widespread or diffuse DME not resolved by laser treatment. While generally it is advocated after 6 months of waiting for a vitreous hemorrhage to clear, early vitrectomy is recommended in type 1 diabetic patients (within 3 months of severe hemorrhage). ${ }^{116-119}$

\section{Vitreolysis}

The vitreoretinal interface plays an important role in the progression of DR. Vitreolysis involves the use of enzymes to liquefy the vitreous gel and induce posterior vitreous detachment. Vitrase, ie, hyaluronidase (bovine), a US Food and Drug Administration (FDA)-approved drug, is often used off-label in clearing vitreous hemorrhage. Research is helping establish the safety and efficacy of intravitreal injection of autologous plasmin enzyme as an adjunct to vitreous surgery in the management of PDR and DME. Some studies have demonstrated the efficacy of plasmin enzyme in reduction of macular thickening in DME and posterior vitreous detachment. ${ }^{120,121}$

\section{Pharmacotherapy of DR}

Pharmacotherapy of DR is still unsatisfactory, as treatment options are limited and display poor efficacy in outcomes. None of the currently available drugs have been able to prevent DR progression or treat the DR. Intravitreal antiinflammatory and antiangiogenic drugs restrict or slow down the further progression of DR and work as an adjunct to other, more definitive therapeutic interventions. Table 2 describes the available and under-research drugs for the treatment of DR. ${ }^{4,122,123}$

\section{Anti-VEGF/angiogenesis inhibitors}

Antiangiogenic agents are emerging as the new gold standard in the management of DR, especially PDR and DME. ${ }^{124,125}$ The most common target of these is VEGF, 
Table 2 Drugs currently available or under investigation for management of DR and their status

\begin{tabular}{|c|c|c|c|}
\hline Drug or formulation & Mechanism or category & $\begin{array}{l}\text { Clinical status/ } \\
\text { regulatory } \\
\text { approval }\end{array}$ & Remarks \\
\hline \multicolumn{4}{|l|}{ Anti-inflammatory } \\
\hline $\begin{array}{l}\text { Intravitreal injection of } \\
\text { triamcinolone acetonide }\end{array}$ & Corticosteroid & Off-label use & $\begin{array}{l}\text { Off-label use in combination with anti-VEGF agents } \\
\text { and as adjunct with surgical intervention for PRP. }\end{array}$ \\
\hline Dexamethasone implant & Corticosteroid & FDA approved & \\
\hline Fluocinolone acetonide & Corticosteroid & FDA approved & \\
\hline Ketorolac & NSAID & Phase II study & Under different clinical and preclinical \\
\hline Nepafenac & NSAID & Phase II study & development phases. \\
\hline Etanercept & TNF- $\alpha$ inhibitor & Preclinical studies & Under different clinical and preclinical \\
\hline Infliximab & TNF- $\alpha$ inhibitor & Phase III study & development phases. \\
\hline Mab2FI & $\begin{array}{l}\text { Monoclonal antibody: Wnt } \\
\text { coreceptor blocker }\end{array}$ & Animal study & \\
\hline \multicolumn{4}{|l|}{ VEGF inhibitors } \\
\hline Bevacizumab & $\begin{array}{l}\text { VEGF inhibitor: monoclonal } \\
\text { antibody }\end{array}$ & Off-label use & $\begin{array}{l}\text { FDA-approved anticancer, off-label use for DR in } \\
\text { conjunction with anti-VEGF agents and surgical } \\
\text { intervention. }\end{array}$ \\
\hline Ranibizumab & $\begin{array}{l}\text { VEGF inhibitor: monoclonal } \\
\text { antibody }\end{array}$ & FDA approved & $\begin{array}{l}\text { FDA approved for DME in } 2014 \text { (AMD 2006; RVO } \\
\text { edema 2010). }\end{array}$ \\
\hline Pegaptanib & VEGF inhibitor: RNA aptamer & Off-label use & $\begin{array}{l}\text { FDA approved for AMD in 2004; Phase III trial } \\
\text { completed for DME. }\end{array}$ \\
\hline Aflibercept & $\begin{array}{l}\text { VEGF inhibitor: decoy receptor } \\
\text { fusion protein }\end{array}$ & FDA approved & $\begin{array}{l}\text { FDA approved for DME in 20I4; also FDA } \\
\text { approved for macular edema following RVO and } \\
\text { neovascular AMD. }\end{array}$ \\
\hline KH902 & VEGF inhibitor: VEGFR decoy & Phase II study & \\
\hline Rapamycin & mTOR inhibitor & Phase II study & \\
\hline Decursin & VEGFR2 phosphorylation & Animal study & \\
\hline Bevasiranib & $\begin{array}{l}\text { Short interfering RNA targeting } \\
\text { VEGF }\end{array}$ & Phase II study & \\
\hline \multicolumn{4}{|l|}{ Angiogenesis inhibitor } \\
\hline TGI0080I & Tyrosine kinase inhibitor & Phase II study & \\
\hline Pazopanib & Tyrosine kinase inhibitor & Animal study & \\
\hline \multicolumn{4}{|l|}{ Aldose reductase inhibitor } \\
\hline ARI-809 & Aldose reductase inhibitor & Animal study & \\
\hline Epalrestat & Aldose reductase inhibitor & Animal study & \\
\hline Fidarestat & Aldose reductase inhibitor & Animal study & \\
\hline Sorbinil & Aldose reductase inhibitor & & \\
\hline Tolrestat & Aldose reductase inhibitor & & \\
\hline \multicolumn{4}{|l|}{ PKC inhibitors } \\
\hline Ruboxistaurin & PKC- $\beta$ inhibitor & Phase III study & \\
\hline PKC-4I2 & PKC- $\beta$ inhibitor & Phase III study & \\
\hline Fasudil & $\begin{array}{l}\text { Rho-associated protein kinase } \\
\text { inhibitor }\end{array}$ & Phase III study & \\
\hline \multicolumn{4}{|c|}{ Growth hormone/insulin-like growth factor inhibitors } \\
\hline Octreotide & Somatostatin analog & Phase III study & \\
\hline Pegvisomant & IGF-IR inhibitor & Preclinical studies & \\
\hline \multicolumn{4}{|l|}{ AGE inhibitors } \\
\hline Aminoguanidine & AGE inhibitor & Phase III study & \\
\hline GLY-230 & Selective inhibitor of glycation & Phase II study & \\
\hline OPB-9195 & AGE inhibitor & Animal study & \\
\hline ALT-7II/Alagebrium & AGE inhibitor & Animal study & \\
\hline LR-90 & AGE inhibitor & Animal study & \\
\hline N-Phenacylthiazolium bromide & AGE inhibitor & Animal study & \\
\hline \multicolumn{4}{|l|}{ Antiplatelet agents } \\
\hline Ticlopidine & ADP receptor inhibitor & & \\
\hline \multicolumn{4}{|l|}{ Vitreous clearing agents } \\
\hline Vitrase (hyaluronidase) & Protease, spreading agent & Phase III & $\begin{array}{l}\text { FDA approved as spreading agent; under Phase } \\
\text { III clinical trial to investigate its promotion of the } \\
\text { clearance of vitreous hemorrhage from PDR. }\end{array}$ \\
\hline
\end{tabular}


Table 2 (Continued)

\begin{tabular}{|c|c|c|}
\hline Drug or formulation & Mechanism or category & $\begin{array}{l}\text { Clinical status/ Remarks } \\
\text { regulatory } \\
\text { approval }\end{array}$ \\
\hline Plasmin & Proteolytic enzyme & \\
\hline Ocriplasmin & $\begin{array}{l}\text { Recombinant protease with activity } \\
\text { against fibronectin and laminin }\end{array}$ & FDA approved \\
\hline \multicolumn{3}{|l|}{ Agents for blood pressure control } \\
\hline $\begin{array}{l}\text { ACE inhibitors: lisinopril, } \\
\text { captopril, enalapril }\end{array}$ & NA & \\
\hline Candesartan, losartan, telmisartan & Angiotensin-2 receptor antagonist & \\
\hline PD I23319 & Angiotensin-2 receptor antagonist & Animal study \\
\hline Valsartan & AT-I receptor antagonist & Animal study \\
\hline Mecamylamine & Nicotinic acetylcholine receptor & Phase II study \\
\hline \multicolumn{3}{|l|}{ Neuroprotective agents } \\
\hline PEgylated PEDF & PEDF bioactive derivative & Animal study \\
\hline S-Nitrosoglutathione & Nitric oxide synthase inhibitor & Animal study \\
\hline \multicolumn{3}{|l|}{ Antioxidants } \\
\hline Baicalein & Flavonoid: lipoxygenase inhibitor & Animal study \\
\hline Apocynin & Reactive oxygen species inhibitor & Animal study \\
\hline Curcumin & PPAR-gamma upregulator & Animal study \\
\hline PJ-34 & PARP inhibitor & Animal study \\
\hline
\end{tabular}

Abbreviations: AGE, advanced glycation end-product; AMD, age-related macular degeneration; DME, diabetic macular edema; DR, diabetic retinopathy; PKC, protein kinase C; VEGF, vascular endothelial growth factor; FDA, Food and Drug Administration; NSAID, nonsteroidal anti-inflammatory drug; PDR, proliferative DR; PEDF, pigment epithelium-derived factor; TNF- $\alpha$, tumor necrosis factor- $\alpha$; PRP, panretinal photocoagulation; RVO, retinal vascular occlusion; NA, not applicable.

based on its well-established prominent role in the progression of DR. Presently, the anti-VEGF molecules which are under investigation for their role in the management of DR are pegaptanib (Macugen), ranibizumab (Lucentis), bevacizumab (Avastin), and aflibercept intravitreal (Eylea). Of all the available anti-VEGF agents, bevacizumab has attracted the most interest because it is economical and has shown good results during its current use as an off-label drug. ${ }^{126}$ It is a recombinant humanized monoclonal antibody that binds to all VEGF-A isoforms. Ranibizumab is another VEGF inhibitor which acts by inhibiting the interaction of VEGF-A with its receptors and thereby suppresses endothelial cell proliferation, neovascularization, and vascular leakage. It has been FDA approved for the management of exudative age-related macular degeneration through intravitreal injections. Pegaptanib is an aptamer that binds specifically only with VEGF-A 165 isoform. Theoretically, it is supposed to be devoid of some side effects of bevacizumab and ranibizumab due to its selectivity. Aflibercept (VEGF Trap-eye) is the newest recombinant VEGF inhibitor that binds at all isoforms of VEGF including VEGF-A and VEGF-B. Unlike bevacizumab and ranibizumab (antibodybased binding), it binds with endogenous VEGF 1 receptor at the second binding domain and VEGF 2 receptors at the third binding domain to inhibit angiogenesis. While the complete significance of this binding is not yet known, it has been used for the management of subfoveal choroidal neovascularization since FDA approval. Its indications for use in DR include DME.

\section{Corticosteroids}

Corticosteroids are potent anti-inflammatory and antiangiogenic agents, which supports the rationale behind their use in the management of DME and PDR. Intravitreal injection of triamcinolone acetonide is an emerging therapy in the management of DME and has shown high efficacy and good outcomes. ${ }^{127}$ Lately, a longer-acting intravitreal or retinal implant of fluocinolone acetonide has been developed which releases the steroid over a prolonged period of time. The side effects include cataract formation, glaucoma, and infection. At present, there is not sufficient evidence supporting the efficacy and safety of the implant on routine use for longer term.

\section{Combination therapy}

Intravitreal steroids and anti-VEGF drugs are often combined in the treatment of DR and macular edema (particularly refractory) with an objective of achieving synergistic activity of the two. Combination therapy has been found to have good results in reducing macular thickness in patients with DME who are otherwise unresponsive to laser therapy. ${ }^{128}$

\section{Novel targets}

With the enhanced understanding of the mechanisms and pathways involved in the development of DR, newer drugs 
are being developed to target specific points in the molecular cascades.

\section{Aldose reductase inhibitors}

Aldose reductase is a rate-limiting enzyme in the polyol pathway and its inhibition is likely to play an important role in modifying the course of progression in DR. Aldose reductase inhibitor ARI-809, epalrestat, sorbinil, and tolrestat are potential agents in the prevention and treatment of DR, but showed no substantial results in clinical studies. ${ }^{129-132}$ In routine clinical practice today, there is no defined role of this group of agents.

\section{PKC inhibitors}

The efficacy of PKC inhibitors is not clear, and results from current studies are expected soon. Ruboxistaurin, a PKC inhibitor, has shown some potential in reducing vision loss, but there is not sufficient evidence to prove its efficacy in preventing or treating progression of DR.

\section{Growth hormone/insulin-like growth factor inhibitors}

The association of growth hormone with progression of DR prompted studies investigating its role in management of DR. ${ }^{52,133,134}$ Two trials investigating the role of a synthetic analog of somatostatin octreotide in DR have shown promising results. ${ }^{135,136}$ However, various other studies have shown no benefit of this agent. ${ }^{137,138}$ There are potentially substantial adverse effects such as hypoglycemic episodes, cholelithiasis, and diarrhea as well as high costs which have curtailed clinical use of this drug for management of DR in clinical practice today. ${ }^{139}$

\section{AGE inhibitors}

A pathogenic role for AGEs in DR is likely. AGE inhibitors such as aminoguanidine are currently being evaluated in trials, but no definitive evidence for their use is available today.

\section{Antiplatelet agents}

A variety of hematologic abnormalities are associated with hyperglycemia, including increased erythrocyte aggregation, increased sensitivity to platelet aggregating agents, decreased red blood cell deformability, and increased platelet aggregation and adhesion. These predispose to sluggish circulation, endothelial damage, and focal capillary occlusion, eventually leading to retinal ischemia. Based on these and other considerations, antiplatelet agents are expected to show efficacy in the management of DR, though existing studies have shown no clear benefit from these agents. ${ }^{140-142}$ In certain studies, aspirin, dipyridamole, and ticlopidine have been reported to prevent some signs of DR such as microaneurysms, but there is not sufficient evidence to prove the efficacy of antiplatelet agents in preventing or treating DR. ${ }^{140-142}$

\section{Topical therapies}

Therapeutically active eyedrop formulations can play an important role in management of DR, but currently there is no topical formulation available for the management of DR. Several approaches with existing molecules having anti-inflammatory, antioxidant, and anti-VEGF activity have been tried, but, in practice, results are not favorable for their clinical use. ${ }^{143,144}$

\section{Nutritional and herbal products}

There are many nutritional supplements and herbal products which are claimed to be effective in the management of DR. Many herbal products and phytoconstituents including curcumin and bioflavonoids possessing antioxidant and anti-inflammatory activity are likely to be efficacious in the management of DR. ${ }^{26,145}$ Despite their popularity and frequent use worldwide, there is no scientific proof regarding their efficacy in clinical use.

\section{Conclusion}

Our understanding of the etiopathogenesis of DR has greatly enhanced over the past few decades, but is still far from satisfactory, as we continue to strive toward finding the perfect therapy for managing DR. The knowledge of clinical and molecular biomarkers has enabled us to provide much better clinical care to diabetic patients and preserve their vision.

The current pharmacotherapy, particularly anti-VEGF agents and corticosteroids, is the outcome of understanding the molecular mechanism of neovascularization in PDR. These drugs now form the mainstay of treatment in the majority of cases where they serve as an important adjunct to laser. Since these need to be used via an intravitreal route, certain risks are involved and research is focusing on drugs which may be administered orally.

Various agents such as aspirin, vitamin E, vitamin C, aldose reductase inhibitors, and $\mathrm{PKC}$ inhibitors which were expected to be promising theoretically have not shown adequate outcomes.

One thing that is now certain is that in view of the multiple and complex pathways involved in the formation of DR, no single standard treatment strategy is sufficient and multiple modes of treatment are needed as a part of the algorithm for 
DR management. Primary prevention of DR and its progression through control of risk factors such as hyperglycemia and dyslipidemia is probably the prime aim of all clinicians.

\section{Disclosure}

The authors report no conflicts of interest in this work.

\section{References}

1. Mohamed Q, Gillies MC, Wong TY. Management of diabetic retinopathy: a systematic review. JAMA. 2007;298(8):902-916.

2. Zhong X, Du Y, Lei Y, Liu N, Guo Y, Pan T. Effects of vitamin D receptor gene polymorphism and clinical characteristics on risk of diabetic retinopathy in Han Chinese type 2 diabetes patients. Gene. 2015;566(2):212-216.

3. Sasongko MB, Wong TY, Nguyen TT, Cheung CY, Shaw JE, Wang JJ. Retinal vascular tortuosity in persons with diabetes and diabetic retinopathy. Diabetologia. 2011;54(9):2409-2416.

4. Cheung N, Mitchell P, Wong TY. Diabetic retinopathy. Lancet. 2010;376(9735):124-136.

5. Bhavsar AR. Diabetic Retinopathy [webpage on the Internet]. New York: WebMD LLC; [upated April 1, 2015]. Available from: http://emedicine. medscape.com/article/1225122-overview\#showall. Accessed July 7, 2015.

6. Imai H, Singh RS, Fort PE, Gardner TW. Neuroprotection for diabetic retinopathy. Dev Ophthalmol. 2009;44:56-68.

7. Lee Y, Wong TY, Sabanayagam C. Epidemiology of diabetic retinopathy, diabetic macular edema and related vision loss. Eye Vis (Lond). $2015 ; 2: 17$

8. International Diabetes Federation. Annual Report 2013. Brussels: International Diabetes Federation; 2014. Available from: http://www.idf. org/sites/default/files/attachments/IDF-AR2013-final-rv.pdf. Accessed August 29, 2015.

9. Safi SZ, Qvist R, Kumar S, Batumalaie K, Ismail IS. Molecular mechanisms of diabetic retinopathy, general preventive strategies, and novel therapeutic targets. Biomed Res Int. 2014;2014:801269.

10. Yau JW, Rogers SL, Kawasaki R, et al; Meta-Analysis for Eye Disease (META-EYE) Study Group. Global prevalence and major risk factors of diabetic retinopathy. Diabetes Care. 2012;35(3):556-564.

11. Lorenzi M. The polyol pathway as a mechanism for diabetic retinopathy: attractive, elusive, and resilient. Exp Diabetes Res. 2007;2007:61038.

12. Obrosova IG, Kador PF. Aldose reductase/polyol inhibitors for diabetic retinopathy. Curr Pharm Biotechnol. 2011;12(3):373-385.

13. Stern DM, Yan SD, Yan SF, Schmidt AM. Receptor for advanced glycation endproducts (RAGE) and the complications of diabetes. Ageing Res Rev. 2002;1(1):1-15.

14. Ahmed N. Advanced glycation endproducts - role in pathology of diabetic complications. Diabetes Res Clin Pract. 2005;67(1): $3-21$.

15. Tarr JM, Kaul K, Chopra M, Kohner EM, Chibber R. Pathophysiology of diabetic retinopathy. ISRN Ophthalmol. 2013;2013:343560.

16. Agrawal SS, Naqvi S, Gupta SK, Srivastava S. Prevention and management of diabetic retinopathy in STZ diabetic rats by Tinospora cordifolia and its molecular mechanisms. Food Chem Toxicol. 2012;50(9): 3126-3132.

17. Ahmed KA, Muniandy S, Ismail IS. Type 2 diabetes and vascular complications: a pathophysiologic view. Biomedical Research. 2010;21: $147-155$.

18. Rema M, Pradeepa R. Diabetic retinopathy: an Indian perspective. Indian J Med Res. 2007;125(3):297-310.

19. Giacco F, Brownlee M. Oxidative stress and diabetic complications. Circ Res. 2010;107(9):1058-1070.

20. Halim EM, Mukhopadhyay AK. Effect of Ocimum sanctum (Tulsi) and vitamin $\mathrm{E}$ on biochemical parameters and retinopathy in streptozotocin induced diabetic rats. Indian J Clin Biochem. 2006;21(2):181-188.
21. Ola MS, Nawaz MI, Siddiquei MM, Al-Amro S, Abu El-Asrar AM. Recent advances in understanding the biochemical and molecular mechanism of diabetic retinopathy. J Diabetes Complications. 2012;26(1): 56-64.

22. Hori S. [Diabetic retinopathy]. Nihon Rinsho. 2005;63 Suppl 2:620-624. Japanese.

23. Kumar B, Gupta SK, Nag TC, et al. Retinal neuroprotective effects of quercetin in streptozotocin-induced diabetic rats. Exp Eye Res. 2014;125:193-202.

24. Kowluru RA, Kowluru V, Xiong Y, Ho YS. Overexpression of mitochondrial superoxide dismutase in mice protects the retina from diabetes-induced oxidative stress. Free Radic Biol Med. 2006;41(8): 1191-1196.

25. Kumar B, Gupta SK, Srinivasan BP, et al. Hesperetin rescues retinal oxidative stress, neuroinflammation and apoptosis in diabetic rats. Microvasc Res. 2013;87:65-74.

26. Kowluru RA, Kanwar M. Effects of curcumin on retinal oxidative stress and inflammation in diabetes. Nutr Metab (Lond). 2007;4:8.

27. Kowluru RA, Chan PS. Oxidative stress and diabetic retinopathy. Exp Diabetes Res. 2007;2007:43603.

28. Joussen AM, Poulaki V, Le ML, et al. A central role for inflammation in the pathogenesis of diabetic retinopathy. FASEB J. 2004;18(12): $1450-1452$

29. Ibrahim AS, El-Shishtawy MM, Peña A Jr, Liou GI. Genistein attenuates retinal inflammation associated with diabetes by targeting of microglial activation. Mol Vis. 2010;16:2033-2042.

30. Gupta SK, Kumar B, Nag TC, et al. Curcumin prevents experimental diabetic retinopathy in rats through its hypoglycemic, antioxidant, and anti-inflammatory mechanisms. J Ocul Pharmacol Ther. 2011;27(2): 123-130.

31. Elmarakby AA, Ibrahim AS, Faulkner J, Mozaffari MS, Liou GI, Abdelsayed R. Tyrosine kinase inhibitor, genistein, reduces renal inflammation and injury in streptozotocin-induced diabetic mice. Vascul Pharmacol. 2011;55(5-6):149-156.

32. Obrosova IG, Minchenko AG, Vasupuram R, et al. Aldose reductase inhibitor fidarestat prevents retinal oxidative stress and vascular endothelial growth factor overexpression in streptozotocin-diabetic rats. Diabetes. 2003;52(3):864-871.

33. Myśliwiec M, Balcerska A, Zorena K, Myśliwska J, Lipowski P, Raczyńska K. The role of vascular endothelial growth factor, tumor necrosis factor alpha and interleukin-6 in pathogenesis of diabetic retinopathy. Diabetes Res Clin Pract. 2008;79(1):141-146.

34. Robinson R, Barathi VA, Chaurasia SS, Wong TY, Kern TS. Update on animal models of diabetic retinopathy: from molecular approaches to mice and higher mammals. Dis Model Mech. 2012;5(4):444-456.

35. Wolter JR. Diabetic retinopathy. Am J Ophthalmol. 1961;51: 1123-1141.

36. Bloodworth JM Jr. Diabetic retinopathy. Diabetes. 1963;12:99-114.

37. Stem MS, Gardner TW. Neurodegeneration in the pathogenesis of diabetic retinopathy: molecular mechanisms and therapeutic implications. Curr Med Chem. 2013;20(26):3241-3250.

38. Yu Y, Chen H, Su SB. Neuroinflammatory responses in diabetic retinopathy. J Neuroinflammation. 2015;12:141.

39. Klein R, Klein BE, Moss SE, Cruickshanks KJ. The Wisconsin Epidemiologic Study of Diabetic Retinopathy: XVII. The 14-year incidence and progression of diabetic retinopathy and associated risk factors in type 1 diabetes. Ophthalmology. 1998;105(10): 1801-1815.

40. Cetin EN, Bulgu Y, Ozdemir S, et al. Association of serum lipid levels with diabetic retinopathy. Int J Ophthalmol. 2013;6(3):346-349.

41. Ferris FL 3rd, Chew EY, Hoogwerf BJ. Serum lipids and diabetic retinopathy. Early Treatment Diabetic Retinopathy Study Research Group. Diabetes Care. 1996;19(11):1291-1293.

42. Rema M, Srivastava BK, Anitha B, Deepa R, Mohan V. Association of serum lipids with diabetic retinopathy in urban South Indians - The Chennai Urban Rural Epidemiology Study (CURES) Eye Study - 2. Diabet Med. 2006;23(9):1029-1036. 
43. Singh R, Dash D, Ansari FJ, Maurya OP, Singh VP. Aldose reductase and diabetic retinopathy. Ann Ophthalmol. 1992;24(11):420-422.

44. Brownlee M. The pathobiology of diabetic complications: a unifying mechanism. Diabetes. 2005;54(6):1615-1625.

45. Alghadyan AA. Diabetic retinopathy - an update. Saudi J Ophthalmol. 2011;25(2):99-111.

46. Demircan N, Safran BG, Soylu M, Ozcan AA, Sizmaz S. Determination of vitreous interleukin-1 (IL-1) and tumour necrosis factor (TNF) levels in proliferative diabetic retinopathy. Eye (Lond). 2006;20(12): 1366-1369.

47. Doganay S, Evereklioglu C, Er H, et al. Comparison of serum NO, TNF-alpha, IL-1beta, sIL-2R, IL-6 and IL-8 levels with grades of retinopathy in patients with diabetes mellitus. Eye (Lond). 2002;16(2): 163-170.

48. Kleinman ME, Baffi JZ, Ambati J. The multifactorial nature of retinal vascular disease. Ophthalmologica. 2010;224 Suppl 1:16-24.

49. Roy S, Ha J, Trudeau K, Beglova E. Vascular basement membrane thickening in diabetic retinopathy. Curr Eye Res. 2010;35(12):1045-1056.

50. Anderson HR, Stitt AW, Gardiner TA, Archer DB. Diabetic retinopathy: morphometric analysis of basement membrane thickening of capillaries in different retinal layers within arterial and venous environments. Br J Ophthalmol. 1995;79:1120-1123.

51. Ray BS, Pazianos AG, Greenberg E, Peretz WL, McLean JM. Pituitary ablation for diabetic retinopathy. I. Results of hypophysectomy (A ten-year evaluation). JAMA. 1968;203(2):79-84.

52. Koller EA, Green L, Gertner JM, Bost M, Malozowski SN. Retinal changes mimicking diabetic retinopathy in two nondiabetic, growth hormone-treated patients. J Clin Endocrinol Metab. 1998;83(7): 2380-2383.

53. Stitt AW, Bhaduri T, McMullen CB, Gardiner TA, Archer DB. Advanced glycation end products induce blood-retinal barrier dysfunction in normoglycemic rats. Mol Cell Biol Res Commun. 2000;3(6):380-388.

54. Goh SY, Cooper ME. Clinical review: the role of advanced glycation end products in progression and complications of diabetes. $J$ Clin Endocrinol Metab. 2008;93(4):1143-1152.

55. Kowluru RA. Effect of reinstitution of good glycemic control on retinal oxidative stress and nitrative stress in diabetic rats. Diabetes. 2003;52(3):818-823.

56. Pan HZ, Zhang H, Chang D, Li H, Sui H. The change of oxidative stress products in diabetes mellitus and diabetic retinopathy. Br J Ophthalmol. 2008;92(4):548-551.

57. da Silva SB, Costa JP, Pintado ME, Ferreira DC, Sarmento B. Antioxidants in the prevention and treatment of diabetic retinopathy $-\mathrm{a}$ review. J Diabetes Metab. 2010;1:111.

58. Lasta M, Pemp B, Schmidl D, et al. Neurovascular dysfunction precedes neural dysfunction in the retina of patients with type 1 diabetes. Invest Ophthalmol Vis Sci. 2013;54(1):842-847.

59. Garhöfer G, Zawinka C, Resch H, Kothy P, Schmetterer L, Dorner GT. Reduced response of retinal vessel diameters to flicker stimulation in patients with diabetes. Br J Ophthalmol. 2004;88(7):887-891.

60. Bek T, Hajari J, Jeppesen P. Interaction between flicker-induced vasodilatation and pressure autoregulation in early retinopathy of type 2 diabetes. Graefes Arch Clin Exp Ophthalmol. 2008;246(5):763-769.

61. Lott ME, Slocomb JE, Shivkumar V, et al. Comparison of retinal vasodilator and constrictor responses in type 2 diabetes. Acta Ophthalmol. 2012;90(6):e434-e441.

62. Antonetti DA, Klein R, Gardner TW. Diabetic retinopathy. $N$ Engl $J$ Med. 2012;366(13):1227-1239.

63. Ng JS, Bearse MA Jr, Schneck ME, Barez S, Adams AJ. Local diabetic retinopathy prediction by multifocal ERG delays over 3 years. Invest Ophthalmol Vis Sci. 2008;49(4):1622-1628.

64. Harrison WW, Bearse MA Jr, Ng JS, et al. Multifocal electroretinograms predict onset of diabetic retinopathy in adult patients with diabetes. Invest Ophthalmol Vis Sci. 2011;52(2):772-777.

65. Gualtieri M, Bandeira M, Hamer RD, Damico FM, Moura AL, Ventura DF. Contrast sensitivity mediated by inferred magno- and parvocellular pathways in type 2 diabetics with and without nonproliferative retinopathy. Invest Ophthalmol Vis Sci. 2011;52(2):1151-1155.
66. Jackson GR, Scott IU, Quillen DA, Walter LE, Gardner TW. Inner retinal visual dysfunction is a sensitive marker of non-proliferative diabetic retinopathy. Br J Ophthalmol. 2012;96(5):699-703.

67. Greenstein VC, Thomas SR, Blaustein H, Koenig K, Carr RE. Effects of early diabetic retinopathy on rod system sensitivity. Optom Vis Sci. 1993;70(1):18-23.

68. Parravano M, Oddone F, Mineo D, et al. The role of Humphrey Matrix testing in the early diagnosis of retinopathy in type 1 diabetes. $\mathrm{Br} \mathrm{J}$ Ophthalmol. 2008;92(12):1656-1660.

69. Park HY, Kim IT, Park CK. Early diabetic changes in the nerve fibre layer at the macula detected by spectral domain optical coherence tomography. Br J Ophthalmol. 2011;95(9):1223-1228.

70. van Dijk HW, Verbraak FD, Kok PH, et al. Decreased retinal ganglion cell layer thickness in patients with type 1 diabetes. Invest Ophthalmol Vis Sci. 2010;51(7):3660-3665.

71. Reiter CE, Gardner TW. Functions of insulin and insulin receptor signaling in retina: possible implications for diabetic retinopathy. Prog Retin Eye Res. 2003;22(4):545-562.

72. Rajala RV. Phosphoinositide 3-kinase signaling in the vertebrate retina. $J$ Lipid Res. 2010;51(1):4-22.

73. Rajala RV, Anderson RE. Rhodopsin-regulated insulin receptor signaling pathway in rod photoreceptor neurons. Mol Neurobiol. 2010;42(1): 39-47.

74. Fort PE, Losiewicz MK, Reiter CE, et al. Differential roles of hyperglycemia and hypoinsulinemia in diabetes induced retinal cell death: evidence for retinal insulin resistance. PLoS One. 2011;6(10):e26498.

75. Barber AJ, Lieth E, Khin SA, Antonetti DA, Buchanan AG, Gardner TW Neural apoptosis in the retina during experimental and human diabetes. Early onset and effect of insulin. J Clin Invest. 1998;102(4):783-791.

76. Lieth E, Barber AJ, Xu B, et al. Glial reactivity and impaired glutamate metabolism in short-term experimental diabetic retinopathy. Penn State Retina Research Group. Diabetes. 1998;47(5):815-820.

77. Zhang Y, Bhavnani BR. Glutamate-induced apoptosis in neuronal cells is mediated via caspase-dependent and independent mechanisms involving calpain and caspase-3 proteases as well as apoptosis inducing factor (AIF) and this process is inhibited by equine estrogens. BMC Neurosci. 2006;7:49.

78. Pulido JE, Pulido JS, Erie JC, et al. A role for excitatory amino acids in diabetic eye disease. Exp Diabetes Res. 2007;2007:36150.

79. Liu Y, Leo LF, McGregor C, Grivitishvili A, Barnstable CJ, TombranTink J. Pigment epithelium-derived factor (PEDF) peptide eye drops reduce inflammation, cell death and vascular leakage in diabetic retinopathy in Ins2(Akita) mice. Mol Med. 2012;18:1387-1401.

80. Yoshida Y, Yamagishi S, Matsui T, et al. Protective role of pigment epithelium-derived factor (PEDF) in early phase of experimental diabetic retinopathy. Diabetes Metab Res Rev. 2009;25(7):678-686.

81. Barnstable CJ, Tombran-Tink J. Neuroprotective and antiangiogenic actions of PEDF in the eye: molecular targets and therapeutic potential. Prog Retin Eye Res. 2004;23(5):561-577.

82. Shen X, Xie B, Cheng Y, Jiao Q, Zhong Y. Effect of pigment epithelium derived factor on the expression of glutamine synthetase in early phase of experimental diabetic retinopathy. Ocul Immunol Inflamm. 2011;19(4):246-254.

83. Gong Y, Chang ZP, Ren RT, et al. Protective effects of adeno-associated virus mediated brain-derived neurotrophic factor expression on retinal ganglion cells in diabetic rats. Cell Mol Neurobiol. 2012;32(3): 467-475.

84. Seki M, Tanaka T, Nawa H, et al. Involvement of brain-derived neurotrophic factor in early retinal neuropathy of streptozotocin-induced diabetes in rats: therapeutic potential of brain-derived neurotrophic factor for dopaminergic amacrine cells. Diabetes. 2004;53(9):2412-2419.

85. Hammes HP, Federoff HJ, Brownlee M. Nerve growth factor prevents both neuroretinal programmed cell death and capillary pathology in experimental diabetes. Mol Med. 1995;1(5):527-534.

86. Ali TK, Al-Gayyar MM, Matragoon S, et al. Diabetes-induced peroxynitrite impairs the balance of pro-nerve growth factor and nerve growth factor, and causes neurovascular injury. Diabetologia. 2011;54(3): $657-668$. 
87. Barber AJ, Gardner TW, Abcouwer SF. The significance of vascular and neural apoptosis to the pathology of diabetic retinopathy. Invest Ophthalmol Vis Sci. 2011;52(2):1156-1163.

88. Banday MZ, Bashir A, Haq E. Molecular pathobiology of diabetic retinopathy. Bioresearch Bulletin. 2010;3:102-115.

89. Nunes S, Pires I, Rosa A, Duarte L, Bernardes R, Cunha-Vaz J. Microaneurysm turnover is a biomarker for diabetic retinopathy progression to clinically significant macular edema: findings for type 2 diabetics with nonproliferative retinopathy. Ophthalmologica. 2009; 223(5):292-297.

90. Haritoglou C, Kernt M, Neubauer A, et al. Microaneurysm formation rate as a predictive marker for progression to clinically significant macular edema in nonproliferative diabetic retinopathy. Retina. 2014;34(1):157-164.

91. Ribeiro L, Bandello F, Tejerina AN, et al; Evicr Net Study Group. Characterization of retinal disease progression in a 1-year longitudinal study of eyes with mild nonproliferative retinopathy in diabetes type 2. Invest Ophthalmol Vis Sci. 2015;56(9):5698-5705.

92. Hernández OH, García-Martínez R, Lizana-Henríquez C, et al. [Optical coherence tomography and visual evoked potentials in patients with type 2 diabetes with and without retinopathy: preliminary report]. Rev Invest Clin. 2014;66(4):330-338. Spanish.

93. Virgili G, Menchini F, Casazza G, et al. Optical coherence tomography (OCT) for detection of macular oedema in patients with diabetic retinopathy. Cochrane Database Syst Rev. 2015;1:CD008081.

94. Jansson RW, Raeder MB, Krohn J. Photopic full-field electroretinography and optical coherence tomography in type 1 diabetic retinopathy. Graefes Arch Clin Exp Ophthalmol. 2015;253(7):989-997.

95. Sim DA, Keane PA, Zarranz-Ventura J, et al. Predictive factors for the progression of diabetic macular ischemia. Am J Ophthalmol. 2013;156(4):684-692.

96. Hellgren KJ, Agardh E, Bengtsson B. Progression of early retinal dysfunction in diabetes over time: results of a long-term prospective clinical study. Diabetes. 2014;63(9):3104-3111.

97. Hellgren KJ, Bengtsson B, Agardh E. Functional and structural change in diabetic eyes. Interim results from an ongoing longitudinal prospective study. Acta Ophthalmol. 2013;91(7):672-677.

98. Sim DA, Keane PA, Rajendram R, et al. Patterns of peripheral retinal and central macula ischemia in diabetic retinopathy as evaluated by ultra-widefield fluorescein angiography. Am J Ophthalmol. 2014;158(1):144-153. e1.

99. Silva PS, Cavallerano JD, Sun JK, Soliman AZ, Aiello LM, Aiello LP. Peripheral lesions identified by mydriatic ultrawide field imaging: distribution and potential impact on diabetic retinopathy severity. Ophthalmology. 2013;120(12):2587-2595.

100. Scholl HP, Zrenner E. Electrophysiology in the investigation of acquired retinal disorders. Surv Ophthalmol. 2000;45(1):29-47.

101. Bearse MA Jr, Ozawa GY. Multifocal electroretinography in diabetic retinopathy and diabetic macular edema. Curr Diab Rep. 2014; 14(9):526.

102. Kinshuck D. HbA1C and Retinopathy [webpage on the Internet]. Available from: http:/www.diabeticretinopathy.org.uk/prevention/ hba1c_and_retinopathy.htm. Accessed July 6, 2015.

103. [No authors listed]. The relationship of glycemic exposure $\left(\mathrm{HbA}_{1 \mathrm{c}}\right)$ to the risk of development and progression of retinopathy in the diabetes control and complications trial. Diabetes. 1995;44(8): 968-983.

104. The Diabetes Control and Complications Trial Research Group. Early worsening of diabetic retinopathy in the Diabetes Control and Complications Trial. Arch Ophthalmol. 1998;116(7):874-886.

105. UKPDS Prospective Diabetes Research Group. Tight blood pressure control and risk of macrovascular and microvascular complications in type 2 diabetes: UKPDS 38. UK Prospective Diabetes Study Group. BMJ. 1998;317(7160): 703-713.

106. van Leiden HA, Dekker JM, Moll AC, et al. Blood pressure, lipids, and obesity are associated with retinopathy: the hoorn study. Diabetes Care. 2002;25(8):1320-1325.
107. Matthews DR, Stratton IM, Aldington SJ, Holman RR, Kohner EM; UK Prospective Diabetes Study Group. Risks of progression of retinopathy and vision loss related to tight blood pressure control in type 2 diabetes mellitus: UKPDS 69. Arch Ophthalmol. 2004;122(11): $1631-1640$

108. Sjølie AK, Porta M, Parving HH, Bilous R, Klein R; DIRECT Programme Study Group. The DIabetic REtinopathy Candesartan Trials (DIRECT) Programme: baseline characteristics. J Renin Angiotensin Aldosterone Syst. 2005;6(1):25-32.

109. Chaturvedi N, Sjolie A, Stephenson JM, et al. Effect of lisinopril on progression of retinopathy in normotensive people with type 1 diabetes. The EUCLID Study Group. EURODIAB Controlled Trial of Lisinopril in Insulin-Dependent Diabetes Mellitus. Lancet. 1998;351: 28-31.

110. Keech A, Simes RJ, Barter P; FIELD study investigators. Effects of long-term fenofibrate therapy on cardiovascular events in 9795 people with type 2 diabetes mellitus (the FIELD study): randomised controlled trial. Lancet. 2005;366(9500):1849-1861.

111. Sen K, Misra A, Kumar A, Pandey RM. Simvastatin retards progression of retinopathy in diabetic patients with hypercholesterolemia. Diabetes Res Clin Pract. 2002;56:1-11.

112. Rohan TE, Frost CD, Wald NJ. Prevention of blindness by screening for diabetic retinopathy: a quantitative assessment. BMJ. 1989;299(6709):1198-1201.

113. [No authors listed]. Photocoagulation for proliferative diabetic retinopathy: a randomised controlled clinical trial using the xenon-arc. Diabetologia. 1984;26(2):109-115.

114. Hercules BL, Gayed II, Lucas SB, Jeacock J. Peripheral retinal ablation in the treatment of proliferative diabetic retinopathy: a three-year interim report of a randomised, controlled study using the argon laser. Br J Ophthalmol. 1977;61(9):555-563.

115. [No authors listed]. Photocoagulation treatment of proliferative diabetic retinopathy: the second report of diabetic retinopathy study findings. Ophthalmology. 1978;85(1):82-106.

116. Ho T, Smiddy WE, Flynn HW Jr. Vitrectomy in the management of diabetic eye disease. Surv Ophthalmol. 1992;37(3):190-202.

117. Sabrosa NA. Surgical Management of Diabetic Retinopathy [webpage on the Internet]. Newtown Square: Review of Ophthalmology; 2009. Available from: http://www.reviewofophthalmology.com/content/d/ retinal_insider/i/1218/c/22941/. Accessed July 6, 2015.

118. The Diabetic Retinopathy Vitrectomy Research Group. Early vitrectomy for severe vitreous hemorrhage in diabetic retinopathy. Two-year results of a randomized trial. Diabetic Retinopathy Vitrectomy Study report 2. The Diabetic Retinopathy Vitrectomy Study Research Group. Arch Ophthalmol. 1985;103(11):1644-1652.

119. [No authors listed]. Early vitrectomy for severe vitreous hemorrhage in diabetic retinopathy. Four-year results of a randomized trial: Diabetic Retinopathy Vitrectomy Study Report 5. Arch Ophthalmol. 1990;108(7):958-964

120. El-Asrar AM, Al-Mezain HS. Pharmacologic vitreolysis in diabetic retinopathy. Curr Pharm Biotechnol. 2011;12(3):406-409.

121. Li C, Chen P, Zhang J, et al. Enzyme-induced vitreolysis can alleviate the progression of diabetic retinopathy through the HIF-1 $\alpha$ pathway. Invest Ophthalmol Vis Sci. 2013;54(7):4964-4970.

122. Opere CA, O’Brien KK, Shea JL. Understanding diabetic retinopathy. US Pharm. 2011;36(4):46-52.

123. Kampik A. Laser, intravitreal drug application, and surgery to treat diabetic eye disease. Oman J Ophthalmol. 2013;6(Suppl 1): S26-S31.

124. Ozdek S, Unlu M, Gurelik G, Hasanreisoglu B. Intravitreal antiVEGF therapy as an adjunct to laser photocoagulation for severe aggressive posterior retinopathy of prematurity. J Optom. 2013;6(1): 51-59.

125. Liu Y, Wang M, Morris AD, et al. Glycemic exposure and blood pressure influencing progression and remission of diabetic retinopathy: a longitudinal cohort study in GoDARTS. Diabetes Care. 2013;36(12): 3979-3984. 
126. Goyal S, Lavalley M, Subramanian ML. Meta-analysis and review on the effect of bevacizumab in diabetic macular edema. Graefes Arch Clin Exp Ophthalmol. 2011;249(1):15-27.

127. Grover D, Li TJ, Chong CC. Intravitreal steroids for macular edema in diabetes. Cochrane Database Syst Rev. 2008;1:CD005656.

128. Tsilimbaris MK, Pandeleondidis V, Panagiototglou T, et al. Intravitreal combination of triamcinolone acetonide and bevacizumab (KenacortAvastin) in diffuse diabetic macular edema. Semin Ophthalmol. 2009;24(6):225-230.

129. Sun W, Oates PJ, Coutcher JB, Gerhardinger C, Lorenzi M. A selective aldose reductase inhibitor of a new structural class prevents or reverses early retinal abnormalities in experimental diabetic retinopathy. Diabetes. 2006;55(10):2757-2762.

130. Hotta N, Kawamori R, Fukuda M, Shigeta Y; Aldose Reductase Inhibitor-Diabetes Complications Trial Study Group. Long-term clinical effects of epalrestat, an aldose reductase inhibitor, on progression of diabetic neuropathy and other microvascular complications: multivariate epidemiological analysis based on patient background factors and severity of diabetic neuropathy. Diabet Med. 2012;29(12): 1529-1533.

131. [No authors listed]. A randomized trial of sorbinil, an aldose reductase inhibitor, in diabetic retinopathy. Sorbinil Retinopathy Trial Research Group. Arch Ophthalmol. 1990;108(9):1234-1244.

132. van Gerven JM, Boot JP, Lemkes HH, van Best JA. Effects of aldose reductase inhibition with tolrestat on diabetic retinopathy in a six months double blind trial. Doc Ophthalmol. 1994;87(4):355-365.

133. Wilkinson-Berka JL, Wraight C, Werther G. The role of growth hormone, insulin-like growth factor and somatostatin in diabetic retinopathy. Curr Med Chem. 2006;13(27):3307-3317.

134. Alzaid AA, Dinneen SF, Melton LJ 3rd, Rizza RA. The role of growth hormone in the development of diabetic retinopathy. Diabetes Care. 1994;17(6):531-534.

135. Grant MB, Mames RN, Fitzgerald C, et al. The efficacy of octreotide in the therapy of severe nonproliferative and early proliferative diabetic retinopathy: a randomized controlled study. Diabetes Care. 2000;23(4):504-509.

136. Sönksen PH, Russell-Jones D, Jones RH. Growth hormone and diabetes mellitus. A review of sixty-three years of medical research and a glimpse into the future? Horm Res. 1993;40(1-3):68-79.
137. Hattori N, Moridera K, Ishihara T, Hino M, Ikekubo K, Kurahachi H. Is growth hormone associated with diabetic retinopathy? J Diabetes Complications. 1993;7(1):12-14.

138. Kirkegaard C, Nørgaard K, Snorgaard O, Bek T, Larsen M, LundAndersen $\mathrm{H}$. Effect of one year continuous subcutaneous infusion of a somatostatin analogue, octreotide, on early retinopathy, metabolic control and thyroid function in type I (insulin-dependent) diabetes mellitus. Acta Endocrinol (Copenh). 1990;122(6):766-772.

139. Bloomgarden ZT. Diabetic retinopathy and diabetic neuropathy. Diabetes Care. 2007;30(3):760-765.

140. Bergerhoff K, Clar C, Richter B. Aspirin in diabetic retinopathy. A systematic review. Endocrinol Metab Clin North Am. 2002;31(3):779-793.

141. The DAMAD Study Group. Effect of aspirin alone and aspirin plus dipyridamole in early diabetic retinopathy. A multicenter randomized controlled clinical trial. Diabetes. 1989;38(4):491-498.

142. Zheng L, Howell SJ, Hatala DA, Huang K, Kern TS. Salicylate-based anti-inflammatory drugs inhibit the early lesion of diabetic retinopathy. Diabetes. 2007;56(2):337-345.

143. Sahoo S, Barua A, Myint KT, Haq A, Abas AB, Nair NS. Topical non-steroidal anti-inflammatory agents for diabetic cystoid macular oedema. Cochrane Database Syst Rev. 2015;2:CD010009.

144. Kaur S, Yangzes S, Singh S, Sachdev N. Efficacy and safety of topical difluprednate in persistent diabetic macular edema. Int Ophthalmol. Epub 2015 Aug 22.

145. Kumar B. To Study Protective Effects of Bioflavonoids on Retinal Neurovascular Degeneration in Diabetic Rats [doctoral thesis synopsis]. New Delhi: University of Delhi; 2003. Available from: http:// shodhganga.inflibnet.ac.in/bitstream/10603/26842/19/19_synopsis. pdf. Accessed September 1, 2015.

146. Dedania VS, Bakri SJ. Novel pharmacotherapies in diabetic retinopathy. Middle East Afr J Ophthalmol. 2015;22(2):164-173.

147. Kumar B, Gupta SK, Saxena R, Srivastava S. Current trends in the pharmacotherapy of diabetic retinopathy. J Postgrad Med. 2012;58(2) 132-139.
Eye and Brain

\section{Publish your work in this journal}

Eye and Brain is an international, peer-reviewed, open access journal focusing on clinical and experimental research in the field of neuroophthalmology. All aspects of patient care are addressed within the journal as well as basic research. Papers covering original research, basic science, clinical and epidemiological studies, reviews and evaluations,

\section{Dovepress}

guidelines, expert opinion and commentary, case reports and extended reports are welcome. The manuscript management system is completely online and includes a very quick and fair peer-review system, which is all easy to use. Visit http://www.dovepress.com/testimonials.php to read real quotes from published authors. 